\title{
Work and health in Latin America: results from the working conditions surveys of Colombia, Argentina, Chile, Central America and Uruguay
}

\author{
Pamela Merino-Salazar, ${ }^{1,2,3,4}$ Lucía Artazcoz, ${ }^{5,6}$ Cecilia Cornelio, ${ }^{7}$ \\ María José Itatí Iñiguez, ${ }^{7}$ Marianela Rojas, ${ }^{8}$ David Martínez-lñigo, ${ }^{9}$ \\ Alejandra Vives, ${ }^{10,11}$ Lorena Funcasta, ${ }^{12}$ Fernando G Benavides ${ }^{1,2,6}$
}

\section{- Additional material is published online only. To view please visit the journal online (http://dx.doi.org/10.1136/ oemed-2016-103899). \\ For numbered affiliations see end of article. \\ Correspondence to Dr Pamela Merino-Salazar, Center for Research in Occupational Health, Edificio PRBB (Campus del Mar) Doctor Aiguader, 88, Barcelona 08003, Spain dramerinos@gmail.com}

Received 12 June 2016 Revised 8 December 2016 Accepted 19 December 2016
To cite: Merino-Salazar $P$, Artazcoz L, Cornelio C, et al. Occup Environ Med Published Online First: [please include Day Month Year] doi:10.1136/oemed2016-103899

\section{ABSTRACT}

Objective To describe working and employment conditions, and health status between non-agricultural employees with a written contract from Colombia, Argentina, Chile, Central America and Uruguay. Methods We compared data from the first working condition surveys (WCS) of Colombia, Argentina, Chile, Central America and Uruguay. For comparative purposes, we selected a subsample of 15241 non-agricultural employees aged 18-64 years and working with a written contract. We calculated prevalences and $95 \% \mathrm{Cls}$ for the selected variables on working and employment conditions, and health status, separated by sex. Results Across all countries, at least $40 \%$ of women and $58 \%$ of men worked $>40$ hours a week. The most prevalent exposures were repetitive movements, followed by noise and manual handling, especially among men. Psychosocial exposures were very common among both sexes. Workers in Chile $33.4 \%$ of women and $16.6 \%$ of men) and Central America (24.3\% of women and 19.1\% of men) were more likely to report poor self-perceived health and were least likely to do so in Colombia (5.5\% of women and $4.2 \%$ of men). The percentage of workers reporting occupational injuries was $<10 \%$ across all countries.

Conclusions This study provides, for the first time, a broad picture of work and health in different Latin American countries, based on the national WCSs available. This allows for a better understanding of occupational health and could serve as a baseline for future research and surveillance of work and health in the Region. However, greater efforts are needed to improve WCSs comparability.

\section{INTRODUCTION}

Working and employment conditions are basic determinants of health and well-being at the individual and population level. ${ }^{1}$ As such, they also have an impact on productivity and competitiveness, playing a significant role in countries' social and economic development. ${ }^{2}{ }^{3}$ Currently, market globalisation is affecting working and employment conditions, especially in economically less developed countries. In fact, this global competition has been leading to different forms of non-standard employment, which are usually linked to precariousness and to the appearance of new job

\section{What this paper adds}

- Recently, several Latin American countries have developed their first working conditions surveys (WCSs), which has improved the information on occupational health at the national level.

- The availability of WCSs in the Region allowed us to compare multiple variables on work and health in non-agricultural employees with a written contract from different Latin American countries.

- We identified multiple common patterns of exposure to poor employment and working conditions, and health status in the studied populations, providing a more comprehensive understanding of occupational health in the Region.

- Although the findings from this study serve as a baseline for research and surveillance of occupational health in the Region, they highlight the need for improving WCSs comparability.

hazards. ${ }^{5}$ Consequently, one of the goals of the 2030 Agenda for Sustainable Development is to "promote sustained, inclusive and sustainable economic growth, full and productive employment and decent work for all". 6

However, one of the main obstacles to developing effective public policies to improve worker's health is the lack of suitable data on occupational health, especially in economically developing countries. In Latin America and the Caribbean, data on occupational health are scarce and poorly standardised, thus limiting cross-country comparability. ${ }^{7}$ In this sense, working conditions surveys (WCSs) are a promising tool to monitor occupational health and to inform policymaking in the Region. Recently, several Latin American countries have introduced their first WCSs and, despite several methodological differences between them, they provide relevant information about a broad range of topics on work and health. ${ }^{8}$

The objective of this study was to describe working and employment conditions, and health status in a comparable sample of non-agricultural 
employees with a written contract in Colombia, Argentina, Chile, Central America (Panama, Costa Rica, Nicaragua, El Salvador, Honduras and Guatemala) and Uruguay, on the basis of the WCSs available in these countries.

\section{METHODS}

\section{Data source and sample selection}

The data have been taken from the first WCSs of Colombia (2007), ${ }^{9}$ Argentina (2009), ${ }^{10}$ Chile (2010-2011), ${ }^{11}$ Central America (2011) ${ }^{12}$ and Uruguay (2012). ${ }^{13}$ The response rate was $79 \%$ in Colombia, $74 \%$ in Chile and $50-80 \%$ in Central America. Argentina and Uruguay did not have this information available.

In all WCSs, sample selection followed a multistage stratified random sampling procedure, but two groups of surveys can be identified based on the site of the interview and the population covered. The first group, comprising surveys of Colombia and Argentina, collected data through a face-to-face interview at the workplace and covered mainly formal employment. The second group, consisting of surveys of Chile, Central America and Uruguay, conducted a face-to-face interview in the respondent's home and covered the whole working population, including informal employment (see online supplementary annex 1). A detailed comparison of the surveys' methodology is available elsewhere. $^{8}$

Given that the Colombian and the Argentinian WCSs covered mainly formal employment (ie, employees with a written contract and social security coverage) and that the latter excluded the primary sector of economic activity, we selected a comparable subsample of workers from all surveys. This subsample consisted of all employees with a written contract, aged 18-64 years, engaged in non-agricultural activities and residing in either Colombia, Argentina, Chile, any of the Spanishspeaking Central American countries (Guatemala, El Salvador, Honduras, Nicaragua, Costa Rica or Panamá, which were considered together in this analysis) or Uruguay. Mining and quarrying activities were also excluded, as the Uruguayan WCS did not include them. Our analysis did not include workers from the public sector in Argentina because they were not included in their WCS. In addition, although having social security coverage is a key element in formal employment relations, it was not used as an inclusion criterion because this information was not available for all surveys. The final sample under analysis consisted of 15241 workers (Colombia $=821$, Argentina $=7048$, Chile $=3850$, Central America $=2666$ and Uruguay $=856$ ).

\section{Measures}

For our analysis, we selected the variables for which data were available in at least three surveys and which were measured with the same or similar questions (see online supplementary annex 2 in Spanish).

\section{General characteristics}

The following sociodemographic measures were selected: sex, age (18-34, 35-49, 50-64), educational level (primary, secondary and tertiary), marital status (married/cohabiting, single, previously married), economic sector (industry, construction or services) and occupational categories according to the International Standard Classification of Occupations (ISCO). The nine original broad categories of the ISCO were collapsed into seven categories as follows: managers; professionals; technicians and associate professionals; clerical support workers; services and sales workers; skilled manual (skilled agricultural, forestry and fishery; craft and related trades workers; plant and machine operators and assemblers); and unskilled manual workers. $^{14}$

\section{Employment conditions}

In this study, we considered workers to be covered by social security if: (1) in Central America they were registered in the social security system; (2) in Colombia they were affiliated to the pension scheme of the social security system; (3) in Chile they were affiliated to the retirement pension scheme of the social security system and (4) in Argentina their retirement pension contributions were being paid. Weekly working hours were categorised as $<30,30-40$ and $>40$ hours.

\section{Working conditions}

We also included several variables on working conditions, including exposure to noise, to vibrations, to handling and to inhalation of chemical substances, to tobacco smoke, to biological agents, to manual handling and to repetitive movements. Given the differences in response categories between surveys, we regarded participants as having been exposed to any of the selected working conditions if they chose any of the response categories other than 'no or never'. Regarding psychosocial working conditions, we measured lack of influence on the order of tasks, lack of influence on the working methods, and working at high speed. For the two former variables, workers were considered to be exposed if they answered that they 'never, very few times or rarely' had influence. In addition, the category 'always' defined workers as being exposed to working at high speed.

\section{Health outcomes}

Two health outcomes were selected. First, self-perceived health status was elicited in each survey by asking respondents to describe their general health. For this question, each survey used different response categories. Colombia and Central America used two different five-point scale versions ranging from excellent to poor and from very good to very poor, respectively, whereas Chile used a seven-point scale version ranging from very poor to very good. For each survey, we created a dichotomous variable, where the category 'fair' and the negative categories indicated poor self-perceived health. Second, we measured occupational injuries only for Colombia, Chile and Central America (yes/no) as these were addressed using the same recall period (previous 12 months). Moreover, within this dimension, we included medical examination, which was elicited by asking the respondents similar questions about whether or not (yes/no) they had the possibility of having a periodic medical examination offered by the employer.

\section{Statistical methods}

We calculated the proportion of individuals in each employment condition and the prevalence of exposure to poor working conditions and of health status, with their respective CIs at 95\%. The sampling weights of each survey database were taken into account. All the analyses were separated by sex. Analyses were conducted using Stata V.11.

\section{RESULTS}

\section{General characteristics}

Table 1 shows the general description of the sample. Overall, $36.3 \%$ of workers were women, and most workers were under 50 years; Chile and Uruguay had the highest proportions of workers aged 50-64. Educational level was higher among 
Table 1 General characteristics of the population sample of Colombia, Argentina, Chile, Central America and Uruguay, by sex

\begin{tabular}{|c|c|c|c|c|c|c|c|c|c|c|}
\hline \multirow[b]{2}{*}{ Characteristic } & \multicolumn{2}{|c|}{ Colombia } & \multicolumn{2}{|c|}{ Argentina } & \multicolumn{2}{|l|}{ Chile } & \multicolumn{2}{|c|}{ Central America } & \multicolumn{2}{|c|}{ Uruguay } \\
\hline & $\mathrm{n}$ & $(\%)$ & $\mathrm{n}$ & $(\%)$ & $\mathrm{n}$ & $(\%)$ & $\mathrm{n}$ & $(\%)$ & $\mathrm{n}$ & $(\%)$ \\
\hline Women & \multicolumn{2}{|l|}{$n=366$} & \multicolumn{2}{|l|}{$n=2646$} & \multicolumn{2}{|l|}{$n=1540$} & \multicolumn{2}{|l|}{$n=1034$} & \multicolumn{2}{|c|}{$n=358$} \\
\hline \multicolumn{11}{|l|}{ Age groups } \\
\hline $18-34$ & 161 & $(44.0)$ & 1293 & $(53.4)$ & 581 & $(40.6)$ & 554 & $(61.2)$ & 149 & (43.4) \\
\hline $35-49$ & 172 & $(47.0)$ & 962 & $(33.2)$ & 621 & (37.8) & 378 & (28.8) & 119 & (32.9) \\
\hline $50-64$ & 33 & (9.0) & 391 & $(13.3)$ & 338 & (21.6) & 102 & $(10.0)$ & 90 & (23.7) \\
\hline \multicolumn{11}{|l|}{ Educational level } \\
\hline Primary & 18 & (4.9) & 148 & (5.4) & 224 & (12.7) & 107 & (11.5) & 35 & (9.8) \\
\hline Secondary & 78 & (21.4) & 836 & $(30.9)$ & 759 & (44.8) & 561 & (54.2) & 225 & $(65.2)$ \\
\hline University & 269 & (73.7) & 1660 & $(63.7)$ & 546 & $(42.5)$ & 365 & (34.3) & 89 & $(25.0)$ \\
\hline \multicolumn{11}{|l|}{ Marital status } \\
\hline Married/cohabiting & - & - & 1259 & $(51.3)$ & 707 & (49.5) & 599 & (54.4) & 152 & $(43.0)$ \\
\hline Single & - & - & 1067 & $(38.9)$ & 555 & (33.6) & 342 & (37.9) & 130 & (38.0) \\
\hline Previously married* & - & - & 319 & $(9.8)$ & 278 & (16.9) & 89 & (7.7) & 75 & (19.0) \\
\hline \multicolumn{11}{|l|}{ Economic activity } \\
\hline Industry & 48 & (13.1) & 464 & $(15.3)$ & 102 & (6.7) & 204 & (16.6) & 135 & (12.1) \\
\hline Construction & 10 & (2.7) & 91 & $(1.8)$ & 19 & (1.7) & 12 & $(0.7)$ & 2 & $(0.1)$ \\
\hline Services & 308 & $(84.2)$ & 2091 & $(82.9)$ & 1419 & (91.6) & 818 & (82.6) & 221 & (87.8) \\
\hline \multicolumn{11}{|l|}{ Occupational categories } \\
\hline Managers & 52 & $(14.2)$ & - & - & 17 & $(1.2)$ & 6 & $(0.6)$ & - & - \\
\hline Professionals & 42 & $(11.5)$ & - & - & 219 & (13.8) & 218 & (23.6) & - & - \\
\hline Technicians & 42 & $(11.5)$ & - & - & 265 & $(17.2)$ & 118 & $(11.5)$ & - & - \\
\hline Clerical support workers & 147 & $(40.2)$ & - & - & 280 & (21.2) & 286 & (27.2) & - & - \\
\hline Services and sales workers & 40 & $(10.9)$ & - & - & 380 & (25.1) & 134 & $(12.7)$ & - & - \\
\hline Skilled manualt & 13 & (3.6) & - & - & 55 & (3.7) & 168 & $(14.4)$ & - & - \\
\hline Unskilled manual & 30 & $(8.2)$ & - & - & 324 & (17.8) & 102 & (9.9) & - & - \\
\hline Men & $n=455$ & & $\mathrm{n}=4402$ & & $n=2310$ & & $n=1632$ & & $\mathrm{n}=498$ & \\
\hline \multicolumn{11}{|l|}{ Age groups } \\
\hline $18-34$ & 184 & $(40.4)$ & 2044 & $(52.3)$ & 743 & (38.5) & 762 & (53.7) & 215 & (46.5) \\
\hline $35-49$ & 216 & $(47.5)$ & 1661 & (33.8) & 975 & (38.1) & 684 & (34.1) & 175 & (34.6) \\
\hline $50-64$ & 55 & $(12.1)$ & 697 & $(13.9)$ & 592 & (23.5) & 186 & $(12.2)$ & 108 & (19.0) \\
\hline \multicolumn{11}{|l|}{ Educational level } \\
\hline Primary & 36 & (7.9) & 704 & $(15.4)$ & 456 & (13.9) & 242 & (17.6) & 112 & (22.5) \\
\hline Secondary & 184 & $(40.5)$ & 2026 & $(46.5)$ & 1318 & (58.1) & 966 & (57.2) & 307 & $(60.8)$ \\
\hline University & 234 & $(51.5)$ & 1654 & $(38.1)$ & 514 & (28.0) & 421 & (25.2) & 65 & (16.8) \\
\hline Marital status & & & & & & & & & & \\
\hline Married/cohabiting & - & - & 2981 & $(62.0)$ & 1646 & (65.4) & 1155 & (67.9) & 294 & $(55.1)$ \\
\hline Single & - & - & 1158 & $(32.2)$ & 544 & $(30.2)$ & 382 & (28.5) & 162 & (37.3) \\
\hline Previously married* & - & - & 260 & $(5.8)$ & 118 & (4.4) & 78 & (3.6) & 38 & (7.6) \\
\hline Economic activity & & & & & & & & & & \\
\hline Industry & 94 & (20.7) & 1262 & $(28.2)$ & 398 & (20.9) & 278 & (15.2) & 217 & (22.4) \\
\hline Construction & 32 & (7.0) & 681 & $(11.6)$ & 448 & (16.4) & 164 & (6.7) & 129 & (10.5) \\
\hline Services & 329 & $(72.3)$ & 2459 & $(60.3)$ & 1464 & (62.7) & 1190 & (78.1) & 152 & (67.1) \\
\hline Occupational categories & & & & & & & & & & \\
\hline Managers & 72 & (15.8) & - & - & 39 & $(2.0)$ & 7 & $(0.5)$ & - & - \\
\hline Professionals & 36 & (7.9) & - & - & 133 & $(7.0)$ & 183 & $(12.5)$ & - & - \\
\hline Technicians & 53 & $(11.6)$ & - & - & 229 & $(11.2)$ & 156 & (10.8) & - & - \\
\hline Clerical support workers & 80 & $(17.6)$ & - & - & 196 & $(10.2)$ & 188 & $(14.0)$ & - & - \\
\hline Services and sales workers & 25 & $(5.5)$ & - & - & 344 & (16.6) & 366 & (23.2) & - & - \\
\hline Skilled manualt & 133 & $(29.2)$ & - & - & 970 & (38.7) & 531 & (27.5) & - & - \\
\hline Unskilled manual & 56 & $(12.3)$ & - & - & 370 & $(14.3)$ & 190 & $(11.5)$ & - & - \\
\hline
\end{tabular}

Non-agricultural employees aged $18-64$ years and working with a written contract.

Unweighted frequencies and weighted percentages, except for Colombia. The variable with the highest percentage of missing values is educational level for men in Uruguay (2.8\%).

*Widowed, separated or divorced.

†Skilled agricultural, forestry and fishery; craft and related trades workers, plant and machines operators, and assemblers. 
women, with Colombia and Argentina having the highest percentages of workers with university level education in both sexes. Most women and men worked in the services sector, and a higher proportion of men than women worked in construction and industry, except for Central America where the percentages of men and women in industry were similar $(15.2 \%$ and $16.6 \%$, respectively). Among women, clerical support was the main occupation in Colombia and Central America (40.2\% and $27.2 \%$, respectively), whereas in Chile the main occupations were clerical support together with service and sales jobs (21.2\% and $25.1 \%$, respectively). Men were more likely to work in skilled manual jobs.

\section{Employment conditions}

Given that the sample consisted of workers with a written contract, almost all workers were covered by social security, except in Central America (84.4\% of women and $85.7 \%$ of men) (table 2). Overall, working $>40$ hours a week was more frequent among men, and working $<30$ hours a week was more frequent among women. However, at least $40 \%$ of women and $58 \%$ of men in each country worked $>40$ hours a week.

\section{Working conditions}

In regard to physical, chemical, biological and ergonomic working conditions, the most frequent exposures for men and women were repetitive movements, ranging from $50.8 \%$ in Argentina to $84.4 \%$ in Colombia, among women; and from $58.6 \%$ in Uruguay to $77.3 \%$ in Central America, among men (table 3). This was followed by noise and manual handling in most countries. Overall, men were more likely to be exposed than women, except for exposure to biological agents and repetitive movements, where the exposure was similar for both sexes. Regarding exposure to psychosocial working conditions, in most countries there were no differences between men and women. Among women, while in Argentina and Central America the most frequent exposure was working at high speed (16\% and $31.4 \%$, respectively), in Uruguay it was less frequent (9.9\%). Among men, the most common exposure was lack of influence on the working methods in Argentina (15.3\%), Chile (46.7\%) and Uruguay (34.8\%).

\section{Health status}

While workers in Chile (33.4\% of women and $16.6 \%$ of men) and Central America (24.3\% of women and 19.1\% of men) were more likely to report poor self-perceived health, workers in Colombia (5.5\% of women and $4.2 \%$ of men) were less likely to do so (table 4). The proportion of workers reporting occupational injuries ranged from $3.8 \%$ of women in Colombia to $7.4 \%$ of women in Chile, and from $4.9 \%$ of men in Central America to $9.9 \%$ of men in Colombia.

\section{DISCUSSION}

This is the first time that large national samples from different WCSs in the Region have been used to describe working and employment conditions and health status in non-agricultural employees with a written contract from different Latin American countries. There are some patterns across countries and differences between them that are worth highlighting. When interpreting these findings, differences in survey methodology should be considered.

\section{Employment conditions}

Regarding employment conditions, it is noteworthy that a large proportion of men and women in the Region work more than 40 hours per week. When comparing our study population with the whole working population in Latin America (ie, formal and informal workers), a similar pattern emerges. According to Economic Commission for Latin America and the Caribbean (CEPAL, by its Spanish acronym), in 2011, the average of weekly working hours among the whole working population in Latin America was 42 hours. This contrasts with the situation in the European Union $^{15}$ and in the Organisation for Economic Cooperation and Development (OECD) countries where the average weekly working hours was 37 hours. ${ }^{16}$ Our findings highlight the widespread magnitude of the problem in the Region, affecting also those who are formally employed. Among formal

Table 2 Employment conditions in Colombia, Argentina, Chile, Central America and Uruguay, by sex

\begin{tabular}{|c|c|c|c|c|c|}
\hline Variables & $\begin{array}{l}\text { Colombia } \\
\%(95 \% \mathrm{Cl})\end{array}$ & $\begin{array}{l}\text { Argentina } \\
\%(95 \% \mathrm{Cl})\end{array}$ & $\begin{array}{l}\text { Chile } \\
\%(95 \% \mathrm{Cl})\end{array}$ & $\begin{array}{l}\text { Central America } \\
\%(95 \% \mathrm{Cl})\end{array}$ & $\begin{array}{l}\text { Uruguay } \\
\%(95 \% \mathrm{Cl})\end{array}$ \\
\hline Women & $n=366$ & $n=2646$ & $n=1540$ & $n=1034$ & $n=358$ \\
\hline Social security coverage & $99.7(99.2 \text { to } 100)^{*}$ & 99.5 (99.1 to 99.7$) \dagger$ & 96.5 (94.8 to 98.1$) \ddagger$ & 84.4 (81.6 to 87.1$) \S$ & - \\
\hline \multicolumn{6}{|l|}{ Weekly working hours } \\
\hline$<30$ & - & 21.8 (16.6 to 27.1$)$ & 5.2 (3.2 to 7.2 ) & $12.4(9.9$ to 14.9$)$ & 17.5 (12.6 to 22.5$)$ \\
\hline $30-40$ & - & 29.0 (24.3 to 33.6$)$ & 31.3 (26.8 to 35.8 ) & 27.1 (24.0 to 30.3 ) & 41.4 (35.1 to 47.6$)$ \\
\hline$>40$ & - & 49.2 (44.1 to 54.4$)$ & 63.5 (58.8 to 68.2 ) & 60.5 (57.0 to 63.9$)$ & 41.1 (34.8 to 47.4 ) \\
\hline Men & $n=455$ & $n=4402$ & $n=2310$ & $n=1632$ & $n=498$ \\
\hline Social security coverage & $99.6(98.9 \text { to } 100)^{*}$ & 99.2 (98.7 to 99.8$) \dagger$ & 97.6 (95.9 to 99.4$) \ddagger$ & 85.7 (83.5 to 87.9$) \S$ & - \\
\hline \multicolumn{6}{|l|}{ Weekly working hours } \\
\hline$<30$ & - & 5.4 (3.4 to 7.5$)$ & $0.9(0.2$ to 1.5$)$ & 5.6 (4.0 to 7.2$)$ & 7.9 (4.6 to 11.1) \\
\hline $30-40$ & - & 18.3 (15.6 to 21.0$)$ & 15.5 (12.8 to 18.2$)$ & 21.0 (18.6 to 23.5 ) & 34.1 (28.4 to 39.8$)$ \\
\hline$>40$ & - & 76.3 (73.1 to 79.4$)$ & 83.6 (80.9 to 86.4$)$ & 73.3 (70.6 to 76.0 ) & 58.1 (52.1 to 64.0$)$ \\
\hline \multicolumn{6}{|c|}{$\begin{array}{l}\text { Non-agricultural employees aged } 18-64 \text { years and working with a written contract. } \\
\text { Weighted percentages, except for Colombia. The variable with the highest percentage of missing values is weekly working hours for women in Chile ( } 5.1 \%) \text {. } \\
\text { *Employees affiliated to the pension scheme of the social security system. } \\
\text { †Employees with retirement pension contributions being paid. } \\
\text { ‡Employees affiliated to the retirement pension scheme of the social security system. } \\
\S \text { Employees registered in the social security system. }\end{array}$} \\
\hline
\end{tabular}


Table 3 Working conditions in Colombia, Argentina, Chile, Central America and Uruguay, by sex

\begin{tabular}{|c|c|c|c|c|c|}
\hline Variables & $\begin{array}{l}\text { Colombia } \\
\%(95 \% \mathrm{Cl})\end{array}$ & $\begin{array}{l}\text { Argentina } \\
\%(95 \% \mathrm{Cl})\end{array}$ & $\begin{array}{l}\text { Chile } \\
\%(95 \% \mathrm{Cl})\end{array}$ & $\begin{array}{l}\text { Central America } \\
\%(95 \% \mathrm{Cl})\end{array}$ & $\begin{array}{l}\text { Uruguay } \\
\%(95 \% \mathrm{Cl})\end{array}$ \\
\hline Women & $n=366$ & $n=2646$ & $\mathrm{n}=1540$ & $\mathrm{n}=1034$ & $\mathrm{n}=358$ \\
\hline \multicolumn{6}{|l|}{ Physical, chemical and ergonomic* } \\
\hline Noise & $23.3(19.0$ to 27.6$)$ & $14.9(11.8$ to 18.0$)$ & 22.5 (18.8 to 26.3$)$ & - & $22.3(17.3$ to 27.4$)$ \\
\hline Vibrations & $6.8(4.3-9.4)$ & 5.5 (3.6 to 7.4$)$ & $11.2(8.2$ to 14.3$)$ & 25.1 (22.2 to 28.1$)$ & $7.9(4.9$ to 10.9$)$ \\
\hline Handling of chemical or hazardous substances & 8.8 (5.9 to 11.7$)$ & $11.9(6.7$ to 17.1$)$ & 9.6 (7.1 to 12.2$)$ & $16.9(14.4$ to 19.5$)$ & 6.4 (3.7 to 9.1$)$ \\
\hline Breathing of chemical substances & $19.2(15.2$ to 23.3$)$ & 2.6 (1.6 to 3.6$)$ & 7.3 (4.8 to 9.7$)$ & $30.8(27.7$ to 34.0$)$ & $14.0(9.7$ to 18.2$)$ \\
\hline Tobacco smoke & $8.8(5.9$ to 11.7$)$ & - & 16.5 (12.6 to 20.5$)$ & $11.2(9.0$ to 13.4$)$ & 6.0 (3.1 to 8.9$)$ \\
\hline Biological agents & $8.2(5.4$ to 11.0$)$ & $9.4(6.5$ to 12.3$)$ & 17.7 (14.0 to 21.4$)$ & $9.9(7.8$ to 11.9$)$ & $12.3(8.3$ to 16.2$)$ \\
\hline Manual handling & $13.4(9.9$ to 16.9$)$ & 24.1 (19.9 to 28.3$)$ & 24.0 (20.1 to 27.9$)$ & 13.9 (11.5 to 16.2$)$ & 27.8 (22.3 to 33.4$)$ \\
\hline Repetitive movements & $84.4(80.7$ to 88.1$)$ & $50.8(45.6$ to 56.0$)$ & 54.7 (49.9 to 59.5$)$ & 73.7 (70.7 to 76.7$)$ & $51.3(45.0$ to 57.8$)$ \\
\hline \multicolumn{6}{|l|}{ Psychosocialt } \\
\hline Lack of influence on the order of tasks & - & 9.5 (6.5 to 12.4$)$ & 39.4 (34.6 to 44.2$)$ & 24.8 (21.9 to 44.2$)$ & $35.0(28.7$ to 41.2$)$ \\
\hline Lack of influence on the working methods & - & $12.2(9.5$ to 14.9$)$ & 42.7 (37.8 to 47.6$)$ & $27.4(24.4$ to 30.5$)$ & 32.4 (26.1 to 38.7$)$ \\
\hline Working at high speed $\ddagger$ & - & $16.0(13.0-19.1)$ & - & $31.4(28.4-34.6)$ & $9.9(6.3-13.5)$ \\
\hline Men & $\mathrm{n}=455$ & $n=4402$ & $n=2310$ & $n=1632$ & $\mathrm{n}=498$ \\
\hline \multicolumn{6}{|l|}{ Physical, chemical and ergonomic* } \\
\hline Noise & $45.2(40.6$ to 49.7$)$ & 22.5 (19.7 to 25.2$)$ & 45.6 (41.1 to 50.1$)$ & - & 30.7 (25.6 to 35.8$)$ \\
\hline Vibrations & $30.8(26.6$ to 35.1$)$ & $17.8(15.4$ to 20.2$)$ & $42.1(37.6$ to 46.5$)$ & $37.6(34.79-40.4)$ & 30.0 (24.8 to 35.2$)$ \\
\hline Handling of chemical or hazardous substances & $22.1(18.3$ to 25.9$)$ & 12.5 (10.7 to 14.4$)$ & 19.1 (15.9 to 22.4$)$ & 18.4 (16.2 to 20.6$)$ & 18.3 (13.9 to 22.8$)$ \\
\hline Breathing of chemical substances & $50.9(46.3$ to 55.5$)$ & 11.9 (9.9 to 13.8$)$ & $32.9(28.9$ to 36.9$)$ & 39.4 (36.6 to 42.2 ) & 31.4 (26.1 to 36.8$)$ \\
\hline Tobacco smoke & $14.6(11.3$ to 17.9$)$ & - & $33.8(29.6$ to 38.1$)$ & 21.4 (19.0 to 23.8$)$ & $11.2(7.4$ to 14.9$)$ \\
\hline Biological agents & $8.2(5.6$ to 10.7$)$ & 6.2 (4.7 to 7.6$)$ & $9.2(7.1-11.3)$ & 9.4 (7.7 to 11.2$)$ & $15.1(10.7$ to 19.5$)$ \\
\hline Manual handling & 34.4 (30.0 to 38.7$)$ & $44.9(41.2$ to 48.5$)$ & $39.9(35.7$ to 44.1$)$ & 36.6 (33.9 to 39.3$)$ & 45.5 (39.5 to 51.5$)$ \\
\hline Repetitive movements & 76.9 (73.0 to 80.8$)$ & $62.8(59.1$ to 66.5$)$ & $60.0(55.4$ to 64.7$)$ & 77.3 (74.9 to 79.9$)$ & 58.6 (52.6 to 64.6$)$ \\
\hline \multicolumn{6}{|l|}{ Psychosocialt } \\
\hline Lack of influence on the order of tasks & - & 19.9 (17.4 to 22.3$)$ & $44.6(40.0$ to 49.2$)$ & 27.6 (25.0 to 30.1$)$ & 33.1 (27.3 to 38.8$)$ \\
\hline Lack of influence on the working methods & - & $22.3(19.6$ to 24.9$)$ & 46.7 (42.1 to 51.3$)$ & $28.8(26.2$ to 31.4$)$ & 34.8 (29.0 to 40.6$)$ \\
\hline Working at high speed $\ddagger$ & - & $15.3(12.9$ to 17.6$)$ & - & 33.5 (30.8 to 36.2$)$ & 6.8 (4.0 to 9.6$)$ \\
\hline
\end{tabular}

Table 4 Health status in Colombia, Argentina, Chile, Central America and Uruguay, by sex

\begin{tabular}{|c|c|c|c|c|c|}
\hline Variables & $\begin{array}{l}\text { Colombia } \\
\%(95 \% \mathrm{Cl})\end{array}$ & $\begin{array}{l}\text { Argentina } \\
\%(95 \% \mathrm{Cl})\end{array}$ & $\begin{array}{l}\text { Chile } \\
\%(95 \% \mathrm{Cl})\end{array}$ & $\begin{array}{l}\text { Central America } \\
\%(95 \% \mathrm{Cl})\end{array}$ & $\begin{array}{l}\text { Uruguay } \\
\%(95 \% \mathrm{Cl})\end{array}$ \\
\hline Women & $\mathrm{n}=366$ & $n=2646$ & $n=1540$ & $n=1034$ & $\mathrm{n}=358$ \\
\hline Poor self-perceived health status* & 5.5 (3.1 to 7.8$)$ & - & 33.4 (28.4 to 38.3$)$ & 24.3 (21.3 to 27.2$)$ & - \\
\hline Occupational injuriest & $3.8(1.9$ to 5.8$)$ & - & 7.4 (4.6 to 10.2$)$ & $4.5(3.1$ to 6.0$)$ & - \\
\hline Medical examination $\ddagger$ & - & $22.2(18.5$ to 25.9$)$ & - & $40.7(37.3-44.0)$ & 38.8 (32.3 to 45.3$)$ \\
\hline Men & $\mathrm{n}=455$ & $n=4402$ & $n=2310$ & $n=1632$ & $\mathrm{n}=498$ \\
\hline Poor self-perceived health status* & $4.2(2.3$ to 6.0$)$ & - & 16.6 (13.4 to 19.7$)$ & 19.1 (16.9 to 21.4$)$ & - \\
\hline Occupational injuriest & $9.9(7.1$ to 12.6$)$ & - & 6.5 (4.7 to 8.3 ) & 4.9 (3.7 to 6.1$)$ & - \\
\hline Medical examination $\ddagger$ & - & 36.5 (33.1 to 39.8$)$ & - & $42.0(39.2$ to 44.8$)$ & $48.8(42.4$ to 55.1$)$ \\
\hline
\end{tabular}

employment relationships, national laws concerning working time regulations are the main tools to prevent long weekly working hours. ${ }^{17}$ However, in most of the countries in the Region, the maximum weekly hours limits stipulated in national laws are longer than in the economically developed countries. ${ }^{18} 19$ Given the existing evidence that working long hours has detrimental 
effects on work-life balance, ${ }^{20}$ several health outcomes and health-related behaviours, ${ }^{21}{ }^{22}$ future studies should focus on the health effects of long working hours in the Region.

\section{Working conditions}

In the Region, the most frequent exposure related to physical, chemical and ergonomic working conditions, was repetitive movements, followed by noise and manual handling, with men reporting the highest prevalences. Concerning psychosocial working conditions, working at high speed and lack of influence on the order of tasks and on the working methods were very frequent. Comparisons of our findings with other studies should be undertaken with caution, since criteria used to define exposure to a given poor working condition are often used (eg, at least a quarter of the time, or more than half of a working day.) Nevertheless, we identified some similar patterns of exposure between our study population and workers in other countries, which are worth noting. For example, according to the European Working Conditions Survey (EWCS) in 2010, ${ }^{23}$ the Korean Working Conditions Survey in $2006^{24}$ and the Spanish Working Conditions Survey in $2011,{ }^{25}$ repetitive movements was the most prevalent exposure in Korea (71\%), in Spain $(59 \%)$ and in the 27 member states of the European Union (EU27) (63\%). Similarly, manual handling (42\%) and exposure to noise (29\%) were among the most frequent exposures reported in the EWCS. The differences in exposures between countries could be related, at least partially, to differences in occupational categories and economic activities. In order to obtain a clearer picture, further studies analysing exposures by sector of economic activity and occupation categories are needed. Moreover, gender differences observed in these exposures are, to a great extent, explained by the horizontal segregation of the labour market. Therefore, given that more men than women worked in industry and construction, they were more likely to be exposed to poor physical, chemical and ergonomic working conditions. As in our population, more than $30 \%$ of workers in the EU- $27^{23}$ and in Korea ${ }^{24}$ reported not being able to influence the order of tasks or the working methods; and as in Central America, a substantial proportion of workers (59\%) in the EU-27 reported working at high speed. The high prevalence of poor ergonomic and psychosocial working conditions in most countries of the Region might be having a negative impact on worker's health. In fact, a recent study which used a sample of workers from the WCS of Central America found a high prevalence of work-related musculoskeletal disorders (MSDs), ranging from $32 \%$ in Panama to $64 \%$ in Nicaragua. ${ }^{26}$ According to a study carried out by the WHO, only one-third of countries worldwide-mainly middle and high income countries-have special programmes for addressing MSDs. ${ }^{27}$ As has been pointed out by the WHO, the International Ergonomics Association and the International Commission on Occupational Health, ${ }^{28}{ }^{29}$ particularly in less developed countries, as in the Latin American ones, there is need for a shift to a more holistic approach to prevent MSDs, including ergonomic risk factors as well as psychosocial risk factors control. This approach should be characterised by simple tools involving participative processes among managers and workers. Therefore, monitoring ergonomic and psychosocial working conditions in the Region should become a priority in order to tackle their negative outcomes.

\section{Health status}

The prevalence of poor self-perceived health status was much lower in Colombia compared with Central America and Chile.
However, the percentages of Central America and Chile are more in line with the percentages provided in other countries through their WCSs. For example, in the Spanish Working Conditions Survey in 2011, 21.3\% of women and $14.2 \%$ of men reported poor health. ${ }^{25}$ Besides real differences in health status, the differences observed could have at least three additional explanations. First, the differences in response categories between the different surveys could have biased the results. In fact, a recent study that compared two different measures of self-rated health across five European countries found that they were not directly comparable. ${ }^{30}$ Second, results could have been affected by cultural differences between countries. In this regard, it has been suggested that cultural factors may influence differences in self-rated health between different ethnic groups. ${ }^{31}$ Third, the highest proportion of older workers in Chile, compared with Colombia and Central America, may partly explain these findings, since older people tend to report worse self-rated health. ${ }^{32}$

However, gender differences in self-rated health observed between Colombia, Chile and Central America might not be affected by the use of different measures, as has been seen in previous studies. ${ }^{33}$ As expected, women were more likely to report poor health status. For instance, among the general population of the EU-28 countries, while $35.6 \%$ of women reported poor health, only $29.7 \%$ of men did so. ${ }^{34}$

Another interesting finding was that among women and men in Colombia, Chile and Central America, the percentages of occupational injuries were close to the estimate drawn by the International Labour Organization (ILO) for low and middle income countries in the American Region in 2010 (6.5\% of the total working population with at least 4 days of absence). ${ }^{35}$ These percentages are higher than estimates from the highest income countries (2.5\%). On the other hand, it should be noted that the number of occupational injuries reported to the ILO represented only $7.2 \%$ of these estimations, showing that more occupational injuries are captured through WCSs in the Region than through national recording and notification systems. Differences between countries could be related to the social meaning given to occupational injuries in each country, which may lead to different interpretations of questions. In addition, contrary to expectations, men in Chile and Central America did not show a higher prevalence of occupational accidents than women. Further analysis would be needed to clarify these findings.

\section{Weaknesses and strengths}

Our findings should be considered in the context of several limitations. First, our sample comprised workers with a written contract and most of them were covered by social security. Thus, it excluded most of the informally employed, accounting for almost half of the working population in the Region. ${ }^{36}$ It should be noted that informal employment is linked to poor employment conditions (eg, temporary employment and long working hours) and hazardous exposures. ${ }^{37} 38$ Moreover, we also excluded workers aged under $18,{ }^{39}$ as well as workers engaged in agriculture, who are also usually exposed to worse working and employment conditions. Thus, future WCSs in the Region should consider strategies to capture the whole working population, including informal employment. Second, the differences between the sites of the interview might have biased our results. It has been shown that in-home interviewing results in more reliable responses than workplace-administered interviews. ${ }^{40}$ In the same line, the sampling frames used in Colombia and Argentina: company registers may have led to select 
workers with higher educational level and upper job categories. Therefore, prevalence of exposure to poor working and employment conditions and health outcomes in Argentina and Colombia might have been underestimated. Third, differences in question wording and response categories between surveys may have limited comparability. Fourth, some variables that are essential for a deeper understanding of work and health were not included in our analysis due to the absence of questions measuring these variables in most surveys; or due to significant differences in question wording, response categories or reference periods. For example, although it is well known that family demands are fundamental determinants of work-related gender inequalities in health, ${ }^{41}$ we were not able to analyse them because they were poorly collected in most WCSs. However, our analysis was separated by sex, although it is not enough to understand gender inequalities in health. Finally, given that our study considered the six Central American countries as a whole, we cannot rule out differences between these countries. In this sense, a previous study based on the first Central American Working Conditions Survey ${ }^{12}$ found poorer working and employment conditions among formal and informal workers in Guatemala, Honduras and El Salvador compared with Costa Rica and Panamá.

Despite these limitations, it is noteworthy that this study offers valuable insights regarding work and health in Latin American countries. In the absence of harmonised data on occupational health between different countries in the Region, our study, based on different large, national samples, is a first attempt to provide an overview of occupational health in different Latin American countries. In addition, it includes a wide range of topics, covering several dimensions on occupational health. Thus, it allows for a more integrated understanding of work and health in the Region.

Hence, future research and initiatives will be needed. First, more studies are needed to examine work and health among informal workers. In addition, these studies should consider the different axes of inequalities: gender, age, ethnicity, social class and geographical area. ${ }^{42}$ Finally, the generation and strengthening of international and multidisciplinary collaboration networks for research and innovation on occupational health in the Region should become a priority. In this sense, a group of experts from academia and public administration of 18 different countries have recently developed a basic questionnaire on Conditions of Work, Employment and Health in Latin America and the Caribbean (CTESLAC, by its acronym in Spanish), and critical methodological recommendations, in order to improve the comparability of the WCSs in the Region. ${ }^{43}$ This kind of initiatives should be maintained and reinforced, in order to promote the development of national and regional occupational health information systems and enhance research opportunities in the Region.

\section{CONCLUSIONS}

These findings provide a baseline for future monitoring of occupational health in the Region. In addition, given that national WCSs in the Region are key tools for occupational health surveillance, efforts focused on improving their comparability should be strengthened. In this sense, as it has been previously mentioned, having a basic questionnaire with a core set of items and common methodological criteria could help to achieve this goal.

\section{Author affiliations}

${ }^{1}$ CISAL (Center for Research in Occupational Health), Universitat Pompeu Fabra, Barcelona, Spain
${ }^{2}$ IMIM (Hospital del Mar Medical Research Institute), Barcelona, Spain

${ }^{3}$ Facultad de Ciencias del Trabajo y Comportamiento Humano, Universidad Internacional SEK, Quito, Ecuador

${ }^{4}$ Secretaría Nacional de Educación Superior, Ciencia, Tecnología e Innovación, Quito, Ecuador

${ }^{5}$ Agència de Salut Pública de Barcelona, Barcelona, Spain

${ }^{6}$ CIBER de Epidemiología y Salud Pública, Spain

${ }^{7}$ Superintendencia de Riesgos del Trabajo, Ministerio de Trabajo, Empleo y

Seguridad Social, Buenos Aires, Argentina

${ }^{8}$ Programa Salud, Trabajo y Ambiente (SALTRA), Universidad Nacional, Heredia,

Costa Rica

${ }^{9}$ Universidad Rey Juan Carlos, Madrid, España

${ }^{10}$ Departamento de Salud Pública, Escuela de Medicina, Pontificia Universidad

Católica de Chile, Santiago de Chile, Chile

${ }^{11}$ CEDEUS, Conicyt-Fondap; ACCDiS, Conicyt-Fondap, Chile

${ }^{12}$ Universidad de la República, Montevideo, Uruguay

Acknowledgements The authors thank Laura Serra for assistance with statistical analyses.

Contributors PM-S contributed to the design of the study, data analyses, interpretation of data and drafting of the work. FGB and LA contributed to the design of the study, interpretation of results and review of the manuscript. All coauthors critically revised the article for important intellectual content.

Funding This study was partially supported by a grant from the Secretaría Nacional de Educación Superior, Ciencia, Tecnología e Innovación del Ecuador.

Competing interests None declared.

Ethics approval Clinical Research Ethical Commitee of the Parc de Salut Mar (CEIC-Parc de Salut Mar).

Provenance and peer review Not commissioned; externally peer reviewed.

\section{REFERENCES}

1 Wilkinson RG, Marmot M. Social determinants of health. The solid facts. 2nd edn. Copenhagen: WHO Regional Office for Europe, 2003.

2 Takala J, Hämäläinen P, Saarela KL, et al. Global estimates of the burden of injury and illness at work in 2012. J Occup Environ Hyg 2014;11:326-37.

3 Croucher R, Stumbitz B, Vickers I, et al. Can better working conditions improve the performance of SMEs? An international literature review. Geneva: ILO, 2013.

4 Kawachi I. Globalization and workers' health. Ind Health 2008:46:421-3.

5 Benach J, Vives A, Amable M, et al. Precarious employment: understanding an emerging social determinant of health. Annu Rev Public Health 2014;35:229-53.

6 United Nations. Transforming our world: the 2030 Agenda for Sustainable Development. https://sustainabledevelopment.un.org/content/documents/ $21252030 \% 20$ Agenda\%20for\%20Sustainable\%20Development\%20web.pdf (accessed Mar 2016).

7 Giuffrida A, lunes RF, Savedoff W. Occupational risks in Latin America and the Caribbean: economic and health dimensions. Health Policy Plan 2002;17:235-46.

8 Merino-Salazar P, Artazcoz L, Campos-Serna J, et al. National working conditions surveys in Latin America: comparison of methodological characteristics. Int I Occup Environ Health 2015:21:266-74.

9 Ministerio de Protección Social. Primera Encuesta Nacional de Condiciones de Salud y Trabajo en el Sistema General de Riesgos Profesionales. http://www.oiss.org/ estrategia/IMG/pdf/I_encuesta_nacional_colombia2.pdf (accessed Mar 2016).

10 Ministerio de Trabajo, Empleo y Seguridad Social. Superintendencia de Riesgos del Trabajo. Encuesta Nacional a Trabajadores, Empleo, Trabajo, Condiciones y Medio Ambiente Laboral. 2010. http://biblioteca.srt.gob.ar/Publicaciones/2013/ EncuestaNac2009.pdf (accessed Feb 2016).

11 Ministerio de Salud, Dirección del Trabajo, Instituto de Seguridad Laboral. Primera Encuesta Nacional de Empleo, Trabajo, Salud y Calidad de Vida de los Trabajadores y las Trabajadoras en Chile (ENETS 2009-2010). Informe Interinstitucional. http:/l www.dt.gob.cl/documentacion/1612/articles-99630_recurso_1.pdf (accessed Jun 2016)

12 Benavides FG, Wesseling C, Delclos GL, et al. Working conditions and health in Central America: a survey of 12024 workers in six countries. Occup Environ Med. 2014;71:459-65.

13 Martínez D, Crego A. I Encuesta sobre Condiciones de Trabajo, Seguridad y Salud Laboral en Uruguay. Informe General. http://www.oiss.org/estrategia/IMG/pdf/ Encuesta_Uruguay.pdf (accessed Jun 2016).

14 International Labour Organization. International Standard Classification of Occupations Structure, group definitions and correspondence tables. 2012. http:/l www.lo.org /wcmsp5/groups/public/---dgreports/---dcomm/---publ/documents/ publication/wcms_172572.pdf (accessed Jun 2016).

15 CEPAL. Panorama social de América Latina 2013. Santiago de Chile: Naciones Unidas, 2013

16 Organisation for Economic Cooperation and Development. OECD. Stat. https://stats. oecd.org/Index.aspx?DataSetCode=ANHRS (accessed May 2016). 


\section{Workplace}

17 International Labour Organization. Working time around the world. Geneva: International Labour Office, 2007

18 International Labour Organization. Travail. Conditions of work and employment program. Working Conditions Laws Database. http://www.ilo.org/dyn/travail/ travmain.home (accessed Jun 2016).

19 International Labour Organization. Working conditions laws report 2012. Geneva: International Labour Office, 2013.

20 Grosch JW, Caruso CC, Rosa RR, et al. Long hours of work in the U.S: associations with demographic and organizational characteristics, psychosocial working conditions, and health. Am J Ind Med 2006;49:943-52.

21 Bannai A, Tamakoshi A. The association between long working hours and health: a systematic review of epidemiological evidence. Scand I Work Environ Health 2014:40:5-18.

22 Artazcoz L, Cortès I, Escribà-Agüir V, et al. Understanding the relationship of long working hours with health status and health-related behaviours. J Epidemiol Community Health 2009;63:521-7.

23 European foundation for the improvement of living and working conditions. European Working Conditions Survey, 2010. https://www.eurofound.europa.eu/es/ surveys/data-visualisation/european-working-conditions-survey-2010 (accessed Jun 2016).

24 Park J, Lee N. First Korean Working Conditions Survey: a comparison between South Korea and EU countries. Ind Health 2009;47:50-4.

25 Instituto Nacional de Seguridad e Higiene en el Trabajo. Encuestas Nacionales de Condiciones de Trabajo y Gestión de la Prevención. Análisis en línea de los datos. http://encuestasnacionales.oect.es/(accessed Jun 2016).

26 Rojas M, Gimeno D, Vargas-Prada S, et al. Dolor musculoesquelético en trabajadores de América Central: resultados de la I Encuesta Centroamericana de Condiciones de Trabajo y Salud. Rev Panam Salud Publica 2015;38:120-8.

27 World Health Organization. WHO Global Plan of Action on Workers' Health (2008-2017): Baseline for Implementation Global Country Survey 2008/2009 executive summary and survey findings. Geneva: World Health Organization, 2013.

28 Caple DC. A toolkit for MSDs prevention-WHO and IEA context. Work 2012;41:3930-2.

29 Scott P, Kogi K, McPhee B. Ergonomics guidelines for occupational health practice in industrially developing countries. IEA, ICOH, 2010.
30 Jürges $H$, Avendano M, Mackenbach JP. Are different measures of self-rated health comparable? An assessment in five European countries. Eur J Epidemiol 2008;23:773-81.

31 Menec VH, Shooshtari S, Lambert P. Ethnic differences in self-rated health among older adults: a cross-sectional and longitudinal analysis. J Aging Health 2007;19:62-86.

32 Kaleta D, Polańska K, Dziankowska-Zaborszczyk E, et al. Factors influencing self-perception of health status. Cent Eur J Public Health 2009;17:122-7.

33 Malmusi D, Artazcoz L, Benach J, et al. Perception or real illness? How chronic conditions contribute to gender inequalities in self-rated health. Eur J Public Health 2012:22:781-6.

34 Eurostat. Self-perceived health statistics. http://ec.europa.eu/eurostat/ statistics-explained/index.php/Self-perceived_health_statistics (Apr 2016).

35 Workplace Safety and Health Institute. Global estimates of occupational accidents and fatal work-related diseases in 2014. Singapore: Workplace Safety and Health Institute, 2014.

36 International Labor Organization. Labour overview. Latin America and the Caribbean 2013; 2013. Lima: ILO/Regional Office for Latin America and the Caribbean, 2013.

37 Muntaner C, Solar O, Vanroelen C, et al. Unemployment, informal work, precarious employment, child labor, slavery, and health inequalities: pathways and mechanisms. Int J Health Serv 2010;40:281-95.

38 López-Ruiz M, Artazcoz L, Martínez JM, et al. Informal employment and health status in Central America. BMC Public Health 2015;15:698.

39 Sturrock S, Hodes M. Child labour in low- and middle-income countries and its consequences for mental health: a systematic literature review of epidemiologic studies. Eur Child Adolesc Psychiatry 2016;12:1273-86.

40 Almódovar A, Nogareda C. VI Encuesta Nacional de Condiciones de Trabajo. El necesario cambio metodológico. Madrid: Instituto Nacional de Seguridad e Higiene del Trabajo (INSHT), 2008.

41 Artazcoz L, Borrell C, Cortès I, et al. Occupational epidemiology and work related inequalities in health: a gender perspective for two complementary approaches to work and health research. J Epidemiol Community Health 2007;61(Suppl 2):ii39-45.

42 Braig M, Costa S, Gobel B. Social inequalities and global interdependences in Latin America: a provisional appraisal. Rev Mex Cienc Polit Soc 2014;223:209-36.

43 Benavides FG, Merino-Salazar P, Cornelio C, et al. Basic questionnaire and methodological criteria for Surveys on Working Conditions, Employment, and Health in Latin America and the Caribbean. Cad Saude Publica 2016;32:9. 


\section{OEM}

Work and health in Latin America: results from the working conditions surveys of Colombia, Argentina, Chile, Central America and Uruguay

Pamela Merino-Salazar, Lucía Artazcoz, Cecilia Cornelio, María José Itatí Iñiguez, Marianela Rojas, David Martínez-Iñigo, Alejandra Vives, Lorena Funcasta and Fernando G Benavides

Occup Environ Med published online January 16, 2017

Updated information and services can be found at:

http://oem.bmj.com/content/early/2017/01/16/oemed-2016-103899

\section{These include:}

References This article cites 22 articles, 7 of which you can access for free at: http://oem.bmj.com/content/early/2017/01/16/oemed-2016-103899 \#BIBL $\begin{array}{cl}\text { Email alerting } & \begin{array}{l}\text { Receive free email alerts when new articles cite this article. Sign up in the } \\ \text { box at the top right corner of the online article. }\end{array}\end{array}$ service

\section{Notes}

To request permissions go to:

http://group.bmj.com/group/rights-licensing/permissions

To order reprints go to:

http://journals.bmj.com/cgi/reprintform

To subscribe to BMJ go to:

http://group.bmj.com/subscribe/ 